\title{
THE CONCEPTUAL MODELS OF E-SERVICE QUALITY TO INCREASE COMMITMENT WAQIF
}

\author{
Lintang Titian Purbasari ${ }^{\mathrm{a}}$ \\ Ririn Tri Ratnasari ${ }^{\mathbf{b}}$ \\ ${ }^{\mathrm{a}, \mathrm{b}}$ Islamic Economics Department, Faculty of Economics and Business, University of Airlangga \\ Email: lintangtitian67@gmail.com ${ }^{\text {a }}$; ririnsari@feb.unair.ac.id ${ }^{b}$
}

ARTICLE HISTORY

Received:

17 June 2021

Revised

19 July 2021

Accepted:

25 November 2021

Online available:

30 November 2021

Keywords:

Cash Waqf,

Commitment,

Charitable Giving

Behaviour,

Social Exchange Theory,

E-Service Quality.

*Correspondence:

Name:

Ririn Tri Ratnasari

E-mail:

ririnsari@feb.unair.ac.id

\section{ABSTRACT}

This study aims to conceptualize the relationship between e-service quality and commitment waqif through e-trust with the moderator variables of communication and religiosity. The conceptual framework was developed from social exchange theory and previous literature on commitment. Nine propositions raised in this study consist of five proposed antecedents of e-service quality, namely environment quality, promotion quality, information quality, system quality, and outcome quality. Then the communication and religiosity factors are proposed no longer as determinants of commitment but as moderators, and e-trust is offered to be a mediator variable between e-service quality and commitment waqif. Many factors can affect commitment waqif, but this study only focuses on the effect of e-service quality. With this conceptual model, it is hoped that the donation platform manager can improve the e-service quality so that donors are loyal to donate through electronic services. In addition, to ease the burden on the government in collecting cash waqf funds and reach the potential that has been set faster. Further researchers can conduct empirical studies by proving all the arguments that have been put forward, also can use other factors that can affect commitment waqif.

\section{INTRODUCTION}

Optimal management of cash waqf will be able to contribute and provide a multiplier effect in both the economic and non-economic sectors (Al-Arif, 2012). The benefits derived from Waqf are also enjoyed by non-Muslim communities. Waqf covers the areas of poverty reduction projects (H. Ahmed \& Salleh, 2016), supporting education development (Ahmad \& Hassan, 2015; Mahamood \& Rahman, 2015), improve the health sector (Htay et al., 2014; Sulaiman \& Zakari, 2015), uphold Islamic sustainability (Rahman et al., 2018; Sulaiman \& Zakari, 2015), help reduce national debt (Ibrahim et al., 2013) and encourage fiscal development (Suhaimi et al., 2014). Thus, the behavior of waqifs or 
waqf donors must be fully understood because they are the main source of charitable gains. Waqf institutions need waqifs or genuine donors to maintain or increase waqf funds for the sustainability of waqf.

The problem highlighted in this study is the difficulty of retaining regular donors. Although cash waqf funds have increased every year, the collection is still not maximized and is far from potential. Based on the report of the chairman of National Committee on Sharia Economics and Finance (KNEKS), the potential for cash waqf in Indonesia is IDR 188 trillion. However, according to BWI records (2020), the cash waqf collected in 2020 reached IDR 391 billion. As technology develops, it will be easier for people to do waqf. Because there is a platform to distribute waqf funds digitally, as is done by Rumah Zakat through the waqf.id platform. It is hoped that cash waqf is a solution for unproductive waqf assets.

The problem of collecting cash waqf has been discussed in previous literature such lack of acceptance of waqf funds (Pitchay et al., 2015); insignificant contribution of cash waqf (Osman et al., 2014); unattractive behavior of giving cash waqf (Osman et al., 2016); and relatively low level of donor acceptance of giving (Mohsin, 2013). The low behavior of giving waqif can be associated with a loss of trust.

Several studies have been conducted on controversies regarding management and service quality. For example, Jalil et al. (2019) stated that information disclosure is the main key to waqif loyalty. Sutomo et al. (2017) mentioned that service quality affects muzzaki loyalty. Likewise, Saputra et al. (2020) explained that the quality of service affects the loyalty of the donors of Dompet Dhuafa Riau. Donors who are satisfied with their values and experience a positive mood towards service will have high loyalty to the platform. However, often disloyal donors are caused from poor service or the quality of electronic services is decreasing from what customers expect (Halpern \& Graham, 2013; Halpern \& Mwesiumo, 2021). The high number of Muslims in Indonesia requires nadhir to be able to manage a waqf website or platform so that the display is more attractive, easy to understand and the necessary information is available. This will have an impact on the level of e-trust of the waqif towards nadhir. The results of research by Ahmed et al. (2015) stated that waqif will donate if the nadhir are responsible and improve their management practices. Charitable organizations must communicate their function in society, for example, obtaining funds for pre-determined project costs, by doing so public trust can lead to the erosion of negative thoughts towards charitable organizations. Honesty, generosity and dependability are the key points that will build trust in the community (Matenge et al., 2015). Thus, this study tries to conceptualize eservice quality in increasing waqif commitment to donate more through waqif e-trust and strengthened by effective communication and religiosity. 


\section{LITERATURE REVIEW}

\section{Overview of Waqf and Cash Waqf}

Waqf comes from Arabic which means to stop, so waqf is to withhold property that is used for good. Waqf based on Law number 41 of 2004 concerning Waqf is a legal act of waqif to separate and or surrender part of his property to be used forever and for a certain period by interests for worship and or general welfare according to sharia. The law of waqf is sunnah. In waqf, immovable objects are generally in the form of land and buildings, usually used for various purposes such as mosques to funerals. Then the party who waqf his property is called Waqif, while the party who receives the waqf property from the waqif to be managed and developed according to its designation is nadhir. In the Qur'an, waqf commands are stated in the QS. Al Baqarah verse 267:

"O you who have believed, spend from the good things which you have earned and from that which We have produced for you from the earth. And do not aim toward the defective therefrom, spending [from that] while you would not take it [yourself] except with closed eyes. And know that Allah is Free of need and Praiseworthy."

Then waqf of movable objects is called cash waqf. According to Saifuddin et al. (2014), the definition of cash waqf is to give a sum of money from one's property that is intended for the general benefit or allocated to several sectors of society. The application of cash waqf is different from other types of waqf. It is not allowed to reduce the value of waqf assets because it is prohibited to use property carelessly or leave it empty. Cash waqf can be converted into capital and then invested, with the profits made distributed to the poor. Therefore, Waqf as an asset is a collective investment and continues to increase (Sanusi \& Shafiai, 2015). In line with the opinion of Harun et al. (2016), those waqf assets should not be sold or disposed of in any form they must be maintained continuously, and any new waqf acquisitions will be added to existing waqf, thus implying that waqf assets are increasing rather than decreasing. In general, according to Mohsin (2013), there are six types of cash waqf schemes, namely cash waqf schemes, cash deposit waqf schemes, mandatory cash waqf schemes, corporate waqf schemes, deposit product waqf schemes, and cooperative waqf schemes.

In addition, there are several advantages of cash waqf compared to waqf in the form of fixed assets. Cash waqf can be a valuable tool to attract more funds and generate liquidity. This may be the best tool in the Islamic mandate to alleviate poverty, especially if nadhir can manage funds effectively (Mohammad, 2015). In addition, cash waqf can generate more economic stimulus and social improvement, its investment can be diversified to generate greater income-generating opportunities and increase growth opportunities (Abdullah, 2018). Empirically, Sanusi and Shafiai (2015) conducted a study on two waqf institutions in Malaysia and proved that waqf contribute to the religious, 
economic, and social sectors. Moreover, waqf have been implemented by the Malaysian government to finance public goods (Ambrose et al., 2018). Mohsin (2013) stated that cash waqf (managed by non-governmental organizations) should be channeled not only into religious sectors, but also other sectors, such as education, health, commercial activities, and infrastructure, for greater benefit. Waqf institutions differ from other social organizations that primarily rely on donations from others (not guaranteeing sustainability) (Shaikh et al., 2017).

\section{Social Exchange Theory}

Social Exchange Theory (SET) was first conceptualized by Homans in 1958 with the title "Social Behavior as Exchange". According to social exchange theory (SET), human relationships are based on a cost-benefit analysis, where further participation in an activity or continuation in a social association result when the perceived benefits outweigh the costs (Benoit (née Moeller) et al., 2016; Yan et al., 2016). Social exchange theory is a suitable framework for studying online social interactions and is widely applied to investigate participation in various online communities and platforms (Gharib et al., 2017; Y. Wang et al., 2019). Social exchange theory is considered as one of the most significant theories and is often applied to understand the motives associated with exchanging personal experiences on digital platforms (Benoit (née Moeller) et al., 2016). This study will use social exchange theory, which is founded on the notion that people are rational beings. Because the transaction is global and not limited to the market economy, the theory of social exchange provides a sociological framework for evaluating charity donations. Because social exchange theory encompasses all attempts to value social experience, including the desire to promote human ideals or spiritual values as well as the pursuit of personal gain and emotional satisfaction, it can be a more useful model for evaluating donor behavior than pure economic theory (Briken et al., 2017).

In this study, the theoretical framework of the Mediated Philanthropy Model (MPM) in the Social Exchange theory developed by Blau in 1964 will be adapted. This model was developed from the Basic Philanthropy Model, which shows the relationship between donors, recipients, and social groups (Jalil et al., 2019). When a donor donates their time or money to a receiver, they will be thanked as well as get social acceptance from their peers. MPM explains the interchange between donors, charitable organizations, beneficiaries, and peers in an enlarged version of the Basic Philanthropy model. The model demonstrates that when a donor donates to a non-profit organization via an application or website, the recipient will respond by offering excellent service in the hopes of the donor donating again. Because their function is to collect, handle, and

Published by University of Airlangga.

This is an open access article under the CC BY license (https://creativecommons.org/licenses/by-nc-sa/4.0/) 
distribute fundraisers, charitable organizations act as intermediaries between donors and beneficiaries.

In this case study, Mediated Philanthropy Model adequately reflects the cash waqf granting process in Indonesia. Indonesian Waqf Board (BWI) is the trustee in Indonesia and acts as a charitable recipient organization. BWI will send the waqf money collected from the waqif to the selected waqf project or beneficiary. In collecting funds online, BWI uses a website or application that has collaborated with partners and nonpartners. However usually, BWI only expresses gratitude through writing on the platform, not too much feedback information is disclosed to the waqif. This is not surprising as BWI is under no obligation to provide waqif performance feedback or other information. Therefore, this study seeks to understand the effect of feedback information in the form of e-service quality on waqif commitment. However, this study not only wants to see why people give but also why people can retain their contributions. In the study of consumer behavior, customer retention is called "loyal". In the field of philanthropy, serious donors who continue to contribute to fundraising have an attitude of commitment. Committed donors are very important to keep the fundraising going.

\section{Charity Giving Behaviour}

Giving is an act of making other people happy, where someone who has excessive funds voluntarily gives his material in the form of money to others. Although giving has been discussed since the sixteenth century by many great economists, the study has only increased in the last third of the twentieth century. The study of charitable giving emerged, particularly with interdependent utility analyses assuming social men rather than economic men and involving social motives such a sense of justice (Sismujito, 2016). Islam encourages believers to help those who are less fortunate among them through charity. This is clearly stated in the Qur'an, "In wealth and property (there are) the rights of the poor, who asks, and who are deprived" (Quran 51:19). Prophet Muhammad SAW also emphasized that "... alms are taken from the rich among them and given to the poor among them". In addition, it also makes the community and the state responsible for reducing the difficulties and poverty of their people through the institutionalization of zakat.

\section{Commitment}

Commitment is a psychological attachment, intention to stay, and ownership of a long-term orientation to the relationship (Yucel, 2012), as long as people feel a relationship is useful (satisfaction) then they will be highly committed. However, much will be lost if the relationship end and the quality of the potential partner is poor. 
Commitment in turn governs the extent to which a person will put aside his interests and act in a pro-relationship manner (AL-Jabari \& Ghazzawi, 2019). Committed means a person will actively maintain their relationship, which increases stability. Experiences associated with promising and contributing can be enriching and significant, possibly related to feelings of competence and self-worth (Carton, 2017). Organizational inducements, such as remuneration, supervisory assistance, and career promotion, are one method businesses increase employees' affective engagement and trust. Employees respond to persuasion by strengthening their trust and emotional attachment to the organization, as well as their willingness to work toward organizational goals, according to the principles of social exchange theory (Kim et al., 2016; Lambert et al., 2020). Within the framework of the psychological contract, this reciprocity of corporate persuasion for employee trust and commitment has been extensively researched. Employees build trust in their employers when they see a positive correlation between promised inducements and actual inducements given. Employees are more devoted, and they frequently reciprocate with favorable conduct toward the company (Sawicki \& Agnew, 2021). As a result, if nadhir provides high-quality electronic services, the waqif will contribute the most and strengthen their faith and dedication to nadhir.

\section{Electronic Service Quality}

Electronic service quality or e-service quality is defined as the extent to which a website facilitates shopping, purchasing, and delivery of products and services effectively and efficiently (Bressolles et al., 2014). E-service quality models are used in various studies not only in determining the level of business success, but are also important for defining customer experience in interactive virtual settings (Al-Jazzazi \& Sultan, 2014; Rahi \& Ghani, 2019; Raza et al., 2015). E-service quality is considered an interactive information facility that allows organizations to differentiate their services and create competitive advantages, through the provision of certain mechanisms (Rowley, 2016). The quality of electronic services that have been perceived by customers well will form a good perception of value about a company. Chou (2014) and Ratnasari et al. (2018) showed that there is a positive relationship between service quality and consumer trust. Thus, consumers who believe in the company will like the company and are expected to maintain their commitment because of the guarantee of good service quality. On the other hand, if consumers do not trust the company, they will not like the company and will move to another place because there is no guarantee of good service quality. Based on the discussion above, we propose:

Published by University of Airlangga.

This is an open access article under the CC BY license (https://creativecommons.org/licenses/by-nc-sa/4.0/) 
$\mathrm{P}_{1}$ : The better e-services quality, the higher waqif e-trust to nadhir, the greater waqif's commitment.

In the mobile context, environment quality represents how consumers consider the overall environment of service delivery by service providers (Zainon et al., 2011; L. Zhao et al., 2012). Many studies treat environment quality as a tangible feature of overall service quality, such as font, color, and design, which reflect the basic requirements for using the service (Awwad, 2012; L. Zhao et al., 2012). Thus, environmental quality is an important factor for the quality of donor agencies' electronic services. According to Sargeant and Jay (2005), people with a better understanding of recipient demands, organizational activities, and the nature of their causes will show significantly higher levels of commitment.

Promotion is a one-way flow of information or persuasion made to direct a person or organization to actions that create exchanges in marketing (Tjiptono, 2015). The promotion has a role as a means of communicating with individuals or organizations that directly or indirectly influence recipients of the information to buy products or services offered by the company (Tambunan \& Nasution, 2013). In this study, nadhir is the party that promotes cash waqf to waqif through digital. When the promotion is well received by the waqif, it will have an impact on increasing the number of donors ( $\mathrm{M} \mathrm{A}$ Camilleri, 2016; Dessart et al., 2015). Because the previous waqif was satisfied and shared the experience with those closest to him, the promotion carried out by nadhir was automatically successful. So that the quality of promotions can affect the quality of digital services and the level of e-trust in waqif.

Information quality is called content quality, and it affects service quality (AlHubaishi et al., 2018). Many studies also treat information quality as an element of cellular service quality (Al-Hubaishi et al., 2018; Awwad, 2012). Zhao et al. (2012)argue that every service provided through mobile devices is influenced by various attributes, one of which is information. As stated by Xie and Ding (2013), the disclosure of financial information of charitable foundations is a guide that can help people and institutions to make donation decisions. Therefore, the disclosure of financial information of charitable foundations can affect the quality of donation platform services, it will automatically have an impact on waqif e-trust and there will no longer be a limited distribution of charitable funds.

System quality refers to the user's perception of the technical level of communication, it is stated that the assessment of the information processing system itself and focuses on the results of the interaction between the user and the system (Zhao et al., 2018). Wang and Lin (2012) argued that, unlike information quality, system quality focuses on the technical side of the system's success. Pakurar et al. (2019) found 
that system reliability, availability, efficiency, and privacy are core themes of system quality. It is important to consider the quality of the system when evaluating services delivered via mobile platforms (Akter et al., 2013; Özer et al., 2013). Due to the many platforms that provide cash waqf fund distribution services, it is important to examine the quality of the system provided by the amil institution, and how it affects the quality of the amil institution's services as a whole so that e-trust of the waqif is maintained.

The quality of the results is what is received by the customer after obtaining the service (Guo et al., 2015). Zhao et al. (2012) showed that the quality of the results reflects the service the customer has recently experienced. In the cellular context, various studies consider outcome quality during service evaluation Zhao et al. (2012), and the most common determinants of outcome quality in the cellular context are services and benefits. The importance of outcome quality is captured by its functional and emotional benefits. Functional benefit refers to the extent to which the service fulfils its purpose. Emotional benefit refers to the extent to which the service evokes positive feelings; for example, when a customer expresses expectations after using a service (Rasoolimanesh et al., 2020). So, in this study, the quality of the results is very important for the waqif because it will have an impact on the level of e-trust in nadhir. Based on the discussion above, we propose:

$\mathrm{P}_{2}$ : The better quality of the environment in the e-services, the higher the waqif e-trust in nadhir.

$\mathrm{P}_{3}$ : The better quality of promotion in the e-services, the higher waqif e-trust in nadhir.

$\mathrm{P}_{4}$ : The better quality of the information in the e-services, the higher the waqif e-trust in nadhir.

$\mathrm{P}_{5}$ : The better quality of the system in the e-services, the higher the waqif e-trust in nadhir.

$\mathrm{P}_{6}$ : The better quality of results in the e-services, the higher waqif e-trust in nadhir.

\section{Electronic Trust}

Electronic trust is a customer's positive expectations that result in a perception of the ability, virtue, and integrity of online-based applications. Ability or competence related to the expertise and reliability of online applications to perform the services requested by customers through mobile applications. Virtue is the possibility of a company holding the interests of consumers above its interests and showing genuine concern for the welfare of customers. Integrity implies that online applications support principles that customers adhere to, keep their promises, and act honestly (Rowley, 2016). Previous research has shown that trust is the cornerstone in building long-term 
relationships between customers and companies (Berraies et al., 2015; Ratnasari et al., 2020). Larivière et al. (2016) found a relationship between trust, commitment, and giving behavior. Perceived communication quality can positively influence donation intentions, but their data suggest that trust can mediate the relationship. According to Shang et al. (2019), the more the client trusts the dealer, the greater the perceived value of the affiliate by the customer, the more likely the client is to remain in the relationship. Of the possible antecedents of commitment that have been listed, trust is the most prominent factor because trust precedes the factions involved to concentrate more on "positive" motivation due to a sense of identification and affiliation with each other. Based on the discussion above, we propose:

$\mathrm{P}_{7}$ : The higher the waqif e-trust to nadhir, the greater waqif's commitment.

\section{Communication}

Communication is the formal and informal sharing of valuable and timely information between companies and customers. This definition will be adopted in this study which means the exchange of information between nadhir and waqif. The purpose of communication is to ensure that the receiver responds in the way that the sender expects (Al-Jabari \& Ghazzawi, 2019). However, the way people interact with each other has evolved. According to Pollock and Hauseman (2019), modern information and communication technologies such as electronic mail and web-based communication via the internet or applications can limit opportunities to influence recipient responses. According to Shang et al. (2019), trust and commitment act sequentially to mediate the function between the giver's perception and their giving behavior. Musheke and Phiri (2021) confirmed that good communication between employees has a positive impact on organizational financial performance. Nadhir is a staff member of an organization that collects waqf funds must adapt and learn the latest information technology to be able to communicate with his donors. The services provided by nadhir through the application or website must be of good quality because this can affect the behavior of donors. So that online interaction is no longer a barrier to not channeling waqf funds. Therefore, the communication variable can strengthen the relationship between e-services quality and the level of e-trust of waqif. Based on the discussion above, we propose:

$\mathrm{P}_{8}$ : The better communication, the stronger relationship between e-service quality and etrust. 


\section{Religiosity}

According to Salleh et al. (2012), religiosity is a state of belief in God, which is characterized by piety and religious zeal. The higher the piety and religious spirit, the stronger the belief in God, which means the higher the value of religiosity. Mutsikiwa and Basera (2012) state that religiosity is the extent to which an individual is committed to his religion so that it has a strong influence on the individual. According to Kasri (2013), religiosity plays an important role in a person's greatest motivation to donate, especially a Muslim who tends to donate because of his responsibility to society. Religiosity influences donation behavior in Indonesia (Asraf, 2014; Ratnasari et al., 2020), Malaysia (Noor et al., 2015), and Pakistan (Awan \& Hameed, 2014). So in this study, it is hoped that religiosity can strengthen the relationship between e-trust and waqif commitment. Based on the discussion above, we propose:

$\mathrm{P}_{9}$ : The stronger religiosity, the stronger relationship between e-trust and waqif's commitment.

\section{RESEARCH METHODS}

This research methodology uses a conceptual framework which is research related to several abstract ideas or theories. This research is generally used by researchers to develop new concepts or existing theories. Conceptual research focuses on concepts or theories that explain the research problem and relates related theories to the phenomenon being studied. In this study, the theory used is social exchange and waqif commitment. This study is compiled based on a review of some of the most recent literature, gathering research-relevant information from previous publications, journals, reports, research papers, websites of various institutions, and all other secondary data useful for this study. Article screening has four stages, namely identification of journal databases, using keywords to search for articles, focusing on the type of article, namely articles based on research, and a minimum year of publication 2011. The goal of this technique is to develop a conceptual instrument for electronic services that encourages waqif commitment, repetition, and practice in order to collect data from multiple researchers' perspectives. 


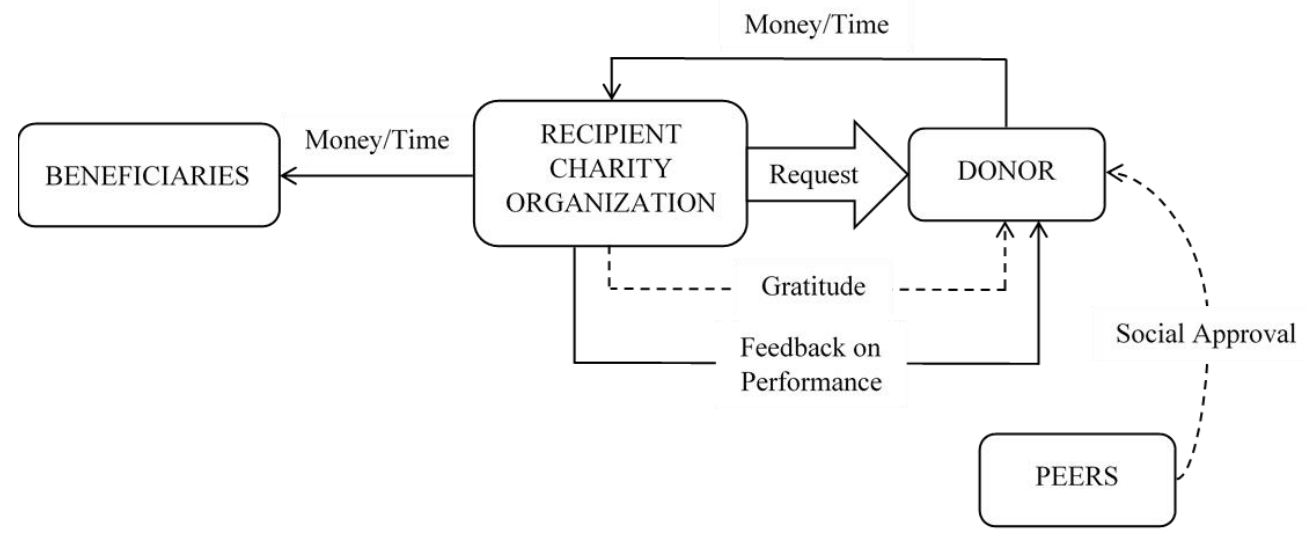

Figure 1. Social Exchange Theory - Mediated Philanthropy Model

Source: Urbonavicius et al. (2021)

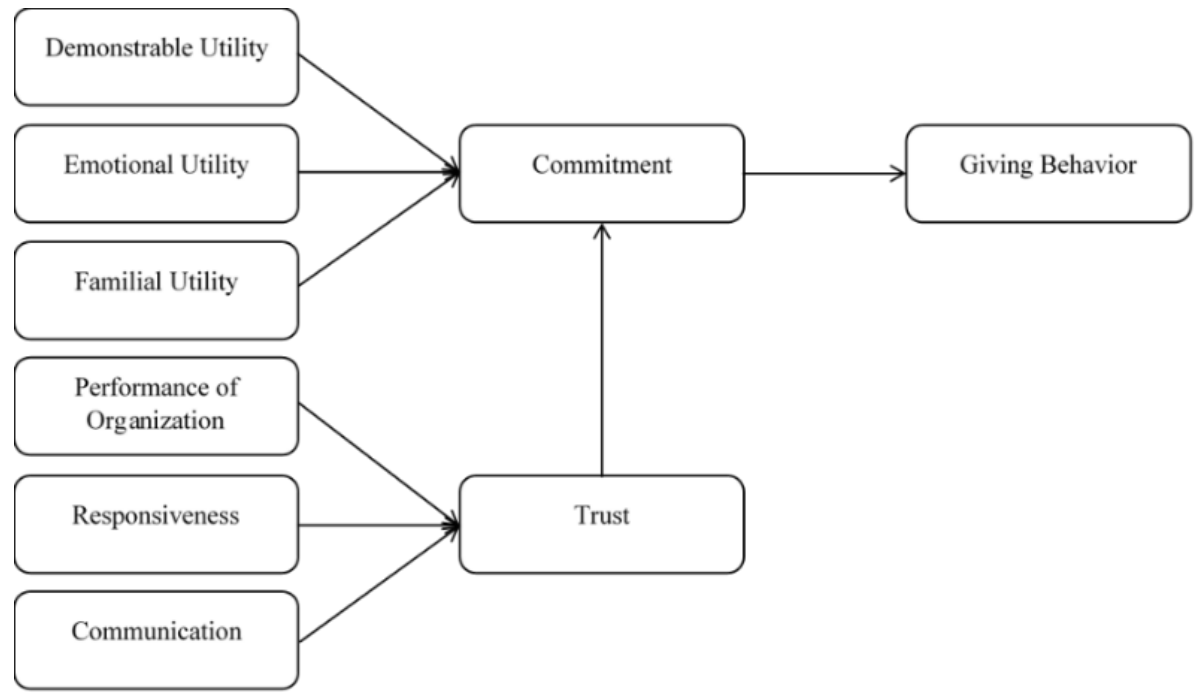

Figure 2. Charity Giving Behaviour

Source: Popoola and Chinomona (2017)

The Mediated Philanthropy Model adequately reflects the process of providing cash waqf in Indonesia. The Indonesian Waqf Board (BWI) will send the waqf money collected from the waqif to the selected waqf project or recipient. Then in Charity Giving Behavior (CGB), the attitude of commitment is influenced by the level of trust and the level of trust is influenced by information about performance, responsiveness, and communication. When a relationship already exists, a higher level of commitment will result based on the presence of trust, and a higher level of loyalty will be obtained as a consequence. Trust, commitment, and giving behavior are linked sequentially. Trust refers to the degree to which the donor believes that the charity will behave as expected and fulfill its obligations. Commitment will always involve some degree of self-sacrifice and is not possible in circumstances where trust does not exist. 


\section{RESULT AND ANALYSIS}

The conceptual framework of this research is illustrated in Figure 3. The difference between this research model and the previous one is that the communication and responsiveness variables are combined in one moderating variable between the quality of electronic services and the level of electronic trust. While CGB only touches on performance information, this study finds that the quality of electronic services in addition to performance has influences such as environmental quality, promotion quality, information quality, system quality, and outcome quality. The "communication" factor is a moderating variable because communication is a means of delivering information. The variable "religiosity" is in the conceptual framework but not in the CGB. The religiosity variable was added based on research by Aysan et al. (2018) which found that religiosity affects customer behavior. However, this study proposes that religiosity is a moderator between the level of e-trust and commitment. Religiosity can be defined as a decision-making process at the beginning and end. Donors gave online after obtaining e-trust and support for additional criteria not included in this study. In general, religiosity has been shown to influence consumer decisions and processes (Garg \& Joshi, 2018). Religion has been found to be a moderating factor in the relationship between e-trust and waqif commitment.

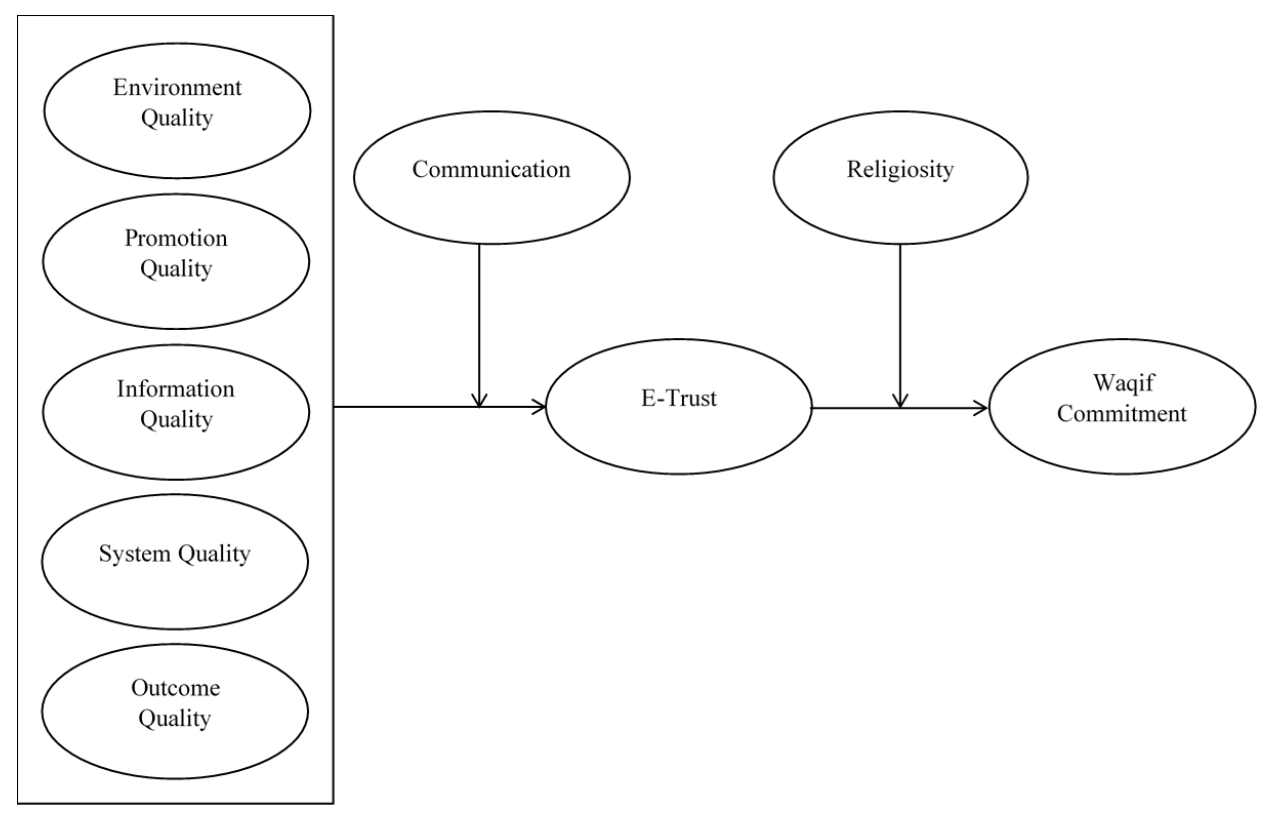

Figure 3. Conceptual Framework

Figure 3 illustrates the relationship between e-service quality as an independent variable and waqif commitment as the dependent variable which is mediated by the 
level of e-trust in waqif and moderated by several variables, namely communication and religiosity. The communication variable will moderate the relationship between e-service quality and e-trust, while religiosity will moderate the relationship between e-trust and waqif commitment. The antecedent variables of e-service quality were adapted from the research of Al-Hubaishi et al. (2018); Camilleri (2018); Jalil et al. (2019); as well as Rahi and Ghani (2019), which consists of environmental quality, promotion quality, information quality, system quality and results quality. These variables become quite important for donors in using the internet as a medium for distributing infaq funds at this time. Due to the quality of electronic services and the entire system, if they are adequate or can meet donor expectations, the level of electronic trust will increase, and waqif commitments can be maintained.

\section{CONCLUSION}

This conceptual research is the first step to initiate a comprehensive study of waqif commitment. The purpose of this study is to conceptualize the relationship between e-service quality and waqif's commitment through e-trust with moderator variables of communication and religiosity. Analysis of the existing literature clearly shows that there is a significant role of communication, responsiveness, and performance information on commitment. However, this study tries to unify past variables that have information related to online fundraising, on a variable called eservice quality as an independent variable. This study tries to prove that the variables of communication and religiosity can be a moderator between e-service quality and e-trust, rather than having a direct relationship with commitment or trust as suggested by previous research. Communication is a means of delivering information. Rich information without any communication is useless and harms the quality of electronic services. Likewise, religiosity can be said as a process of beginning and end in making a decision. The limitations of this study are that the researcher only proposes a conceptual model of e-service quality to increase waqif commitment and the data obtained from previous studies are limited to e-service quality and commitment. However, with this conceptual model, donation platform managers can improve the quality of service on their platform so that donors do not switch and are loyal to donate through electronic services. In addition, for the government to ease the burden of collecting cash waqf funds and reach the potential that has been set faster. Further researchers can conduct empirical studies by proving all the propositions that have been put forward, also can use other factors that can affect the waqif's commitment. 


\section{ACKNOWLEDGEMENT}

I am grateful for thoughtful feedback on previous versions of this research from

Editor, Sylva Alif Rusmita and anonymous reviewers.

\section{REFERENCES}

Abdullah, M. (2018). Waqf, Sustainable Development Goals (SDGs) and maqasid alshariah. International Journal of Social Economics, 45(1), 158-172.

https://doi.org/10.1108/IJSE-10-2016-0295

Ahmad, M., \& Hassan, Y. B. (2015). Funding the Sub - Saharan African education sector with waqf : Experiences from al-Azhar university and selected universities in Malaysia. Journal of Creative Writing, 01(2), 40-54. https://journals.discinternational.org/index.php/jocw/article/view/35/33

Ahmed, H., \& Salleh, A. M. H. A. P. M. (2016). Inclusive Islamic financial planning: a conceptual framework. International Journal of Islamic and Middle Eastern Finance and Management, 9(2), 170-189. https://doi.org/10.1108/IMEFM-01-2015-0006

Ahmed, U., Mohammed, M. O., Faosiy, O. A., \& Daud, N. M. (2015). Investigating the influence of public trust on the revival of waqf institution in Uganda. Middle-East Journal of Scientific Research, 23(6), 1165-1172. https://www.researchgate.net/profile/Umar_Ahmed11/publication/292397600_Inv estigating_the_Influence_of_Public_Trust_on_the_Revival_of_Waqf_Institution_in _Uganda/links/56ae409208ae43a3980e75de.pdf

Akter, S., D'Ambra, J., \& Ray, P. (2013). Development and validation of an instrument to measure user perceived service quality of mHealth. Information \& Management, 50(4), 181-195. https://doi.org/https://doi.org/10.1016/j.im.2013.03.001

Al-Arif, N. R. (2012). Dasar-Dasar Pemasaran Bank Syaria. Alfabeta.

Al-Hubaishi, H. S., Ahmad, S. Z., \& Hussain, M. (2018). Assessing M-Government Application Service Quality and Customer Satisfaction. Journal of Relationship Marketing, 17(3), 229-255. https://doi.org/10.1080/15332667.2018.1492323

AL-Jabari, B., \& Ghazzawi, I. (2019). Organizational Commitment: A Review of the Conceptual and Empirical Literature and a Research Agenda. International Leadership Journal, 11(1), 78-119.

https://www.researchgate.net/publication/331635975_Organizational_Commitme nt_A_Review_of_the_Conceptual_and_Empirical_Literature_and_a_Research_Agen da

Al-Jazzazi, A. M., \& Sultan, P. (2014). Banking service quality in the Middle Eastern countries. International Journal of Bank Marketing, 32(7), 688-700.

https://doi.org/10.1108/IJBM-09-2013-0094

Ambrose, A. H. A. A., Hassan, M. A. G., \& Hanafi, H. (2018). A proposed model for financing public goods and mixed public goods in Malaysia. International Journal of Islamic and Middle Eastern Finance and Management, 11(3), 395-415. https://doi.org/10.1108/IMEFM-01-2017-0001

Asraf, A. (2014). Pengaruh Kualitas Produk Terhadap Keputusan Menyimpan Dana Di 
Bank Muamalat Indonesia Cabang Pasaman Barat Dengan Religiusitas Sebagai Variabel Moderator. Jurnal Apresiasi Ekonomi, 2(1), 61-72.

Awan, M. Y., \& Hameed, F. (2014). The effect of demographic, socio-economic and other characteristics on donations. Current Research Journal of Social Sciences, 6(2), 5576.

Awwad, M. S. (2012). An application of the American Customer Satisfaction Index (ACSI) in the Jordanian mobile phone sector. The TQM Journal, 24(6), 529-541. https://doi.org/10.1108/17542731211270098

Aysan, A. F., Disli, M., Duygun, M., \& Ozturk, H. (2018). Religiosity versus rationality: Depositor behavior in Islamic and conventional banks. Journal of Comparative Economics, 46(1), 1-19. https://doi.org/https://doi.org/10.1016/j.jce.2017.03.001

Benoit (née Moeller), S., Bilstein, N., Hogreve, J., \& Sichtmann, C. (2016). Explaining social exchanges in information-based online communities (IBOCs). Journal of Service Management, 27(4), 460-480. https://doi.org/10.1108/JOSM-09-2015-0287

Berraies, S., Chtioui, R., \& Yahia, K. Ben. (2015). Functional characteristics of banking websites and customer loyalty: the mediating role of online trust. Journal of Applied Business Research (JABR), 31(3), 911-924.

Bressolles, G., Durrieu, F., \& Senecal, S. (2014). A consumer typology based on e-service quality and e-satisfaction. Journal of Retailing and Consumer Services, 21(6), 889896. https://doi.org/https://doi.org/10.1016/j.jretconser.2014.07.004

Briken, K., Chillas, S., Krzywdzinski, M., \& Marks, A. (2017). Labour process theory and the new digital workplace. The New Digital Workplace: How New Technologies Revolutionise Work, 1.

Camilleri, M A. (2016). Responsible tourism that creates shared value among stakeholders. Tourism Planning \& Development, 13(2), 219-235. https://doi.org/10.1080/21568316.2015.1074100

Camilleri, Mark Anthony. (2018). The Promotion of Responsible Tourism Management Through Digital Media. Tourism Planning \& Development, 15(6), 653-671. https://doi.org/10.1080/21568316.2017.1393772

Carton, A. M. (2017). "I'm Not Mopping the Floors, I'm Putting a Man on the Moon": How NASA Leaders Enhanced the Meaningfulness of Work by Changing the Meaning of Work. Administrative Science Quarterly, 63(2), 323-369. https://doi.org/10.1177/0001839217713748

Chou, P.-F. (2014). An evaluation of service quality, trust, and customer loyalty in homedelivery services. International Journal of Research In Social Science, 3(8), 99-108.

Dessart, L., Veloutsou, C., \& Morgan-Thomas, A. (2015). Consumer engagement in online brand communities: a social media perspective. Journal of Product \& Brand Management, 24(1), 28-42. https://doi.org/10.1108/JPBM-06-2014-0635

Garg, P., \& Joshi, R. (2018). Purchase intention of "Halal" brands in India: the mediating effect of attitude. Journal of Islamic Marketing, 9(3), 683-694. https://doi.org/10.1108/JIMA-11-2017-0125

Gharib, R. K., Philpott, E., \& Duan, Y. (2017). Factors affecting active participation in B2B online communities: An empirical investigation. Information \& Management, 54(4), 516-530. https://doi.org/https://doi.org/10.1016/j.im.2016.11.004 
Guo, X., Han, X., Zhang, X., Dang, Y., \& Chen, C. (2015). Investigating m-Health Acceptance from a Protection Motivation Theory Perspective: Gender and Age Differences. Telemedicine and E-Health, 21(8), 661-669. https://doi.org/10.1089/tmj.2014.0166

Halpern, N., \& Graham, A. (2013). Airport Marketing. Routledge.

Halpern, Nigel, \& Mwesiumo, D. (2021). Airport service quality and passenger satisfaction: The impact of service failure on the likelihood of promoting an airport online. Research in Transportation Business \& Management, 100667. https://doi.org/https://doi.org/10.1016/j.rtbm.2021.100667

Htay, S. N. N., Salman, S. A., Myint, S., \& Ilyas, H. (2014). Integrating zakat, waqf and sadaqah: Myint Myat Phu Zin clinic model in Myanmar. Tazkia Islamic Finance and Business Review, 8(2).

Ibrahim, H., Amir, A., \& Masron, T. A. (2013). Cash Waqf: An Innovative Instrument for Economic Development. International Review of Social Sciences and Humanities, 6(1), 1-7.

Jalil, M. I. A., Yahya, S., \& Pitchay, A. A. (2019). Building committed Waqif: the role of information disclosure. Journal of Islamic Accounting and Business Research, 10(2), 185-215. https://doi.org/10.1108/JIABR-05-2016-0058

Kasri, R. A. (2013). Giving behaviors in Indonesia: motives and marketing implications for Islamic charities. Journal of Islamic Marketing, 4(3), 306-324. https://doi.org/10.1108/JIMA-05-2011-0044

Kim, K. Y., Eisenberger, R., \& Baik, K. (2016). Perceived organizational support and affective organizational commitment: Moderating influence of perceived organizational competence. Journal of Organizational Behavior, 37(4), 558-583. https://doi.org/https://doi.org/10.1002/job.2081

Lambert, L. S., Bingham, J. B., \& Zabinski, A. (2020). Affective commitment, trust, and the psychological contract: contributions matter, too! European Journal of Work and Organizational Psychology, 29(2), 294-314.

https://doi.org/10.1080/1359432X.2019.1697743

Larivière, B., Keiningham, T. L., Aksoy, L., Yalçin, A., Morgeson, F. V, \& Mithas, S. (2016). Modeling Heterogeneity in the Satisfaction, Loyalty Intention, and Shareholder Value Linkage: A Cross-Industry Analysis at the Customer and Firm Levels. Journal of Marketing Research, 53(1), 91-109. https://doi.org/10.1509/jmr.12.0143

Mahamood, S. M., \& Ab Rahman, A. (2015). Financing universities through waqf, pious endowment: is it possible? Humanomics, 31(4), 430-453.

https://doi.org/10.1108/H-02-2015-0010

Matenge, T. M., Kealesitse, B., \& Marandu, E. E. (2015). HOW MUCH TO DONATE: THE EFFECT OF DONORS'NATURE ON ATTITUDE TOWARD DONATIONS AND DONATION VALUE. International Journal of Economics, Commerce and Management, 3(1), 112.

Mohammad, M. T. S. H. (2015). Theoretical and trustees' perspectives on the establishment of an Islamic social (Waqf) bank. Humanomics, 31(1), 37-73. 
https://doi.org/10.1108/H-05-2013-0032

Mohsin, M. I. A. (2013). Financing through cash-waqf: a revitalization to finance different needs. International Journal of Islamic and Middle Eastern Finance and Management, 6(4), 304-321. https://doi.org/10.1108/IMEFM-08-2013-0094

Musheke, M. M., \& Phiri, J. (2021). The Effects of Effective Communication on Organizational Performance Based on the Systems Theory. Open Journal of Business and Management, 9(2), 659-671.

Mutsikiwa, M., \& Basera, C. H. (2012). The influence of socio-cultural variables on consumers' perception of halal food products: A case of masvingo urban, zimbabwe. International Journal of Business and Management, 7(20), 112.

Noor, A. H. B. M., Isa, N. A. M., Irpan, H. M., Bahrom, H. Bin, Salleh, A. B. M., \& Ridzuan, A. R. Bin. (2015). Characteristic Affecting Charitable Donations Behavior: Empirical Evidence from Malaysia. Procedia Economics and Finance, 31, 563-572. https://doi.org/https://doi.org/10.1016/S2212-5671(15)01202-2

Osman, A. F., Mohammed, M. O., \& Amin, H. (2014). An analysis of cash waqf participation among young intellectuals.

Osman, A. F., Mohammed, M. O., \& Fadzil, A. (2016). Factor Influencing Cash Waqf Giving Behavior: A Revised Theory Of Planned Behavior. Journal of Global Business and Social Entrepreneurship (GBSE), 1(2), 12-25.

http://gbse.com.my/isimarch16/GBSE 1(2) 12-25 (March 2016).pdf

Özer, A., Argan, M. T., \& Argan, M. (2013). The Effect of Mobile Service Quality Dimensions on Customer Satisfaction. Procedia - Social and Behavioral Sciences, 99, 428-438. https://doi.org/https://doi.org/10.1016/j.sbspro.2013.10.511

Pitchay, A. A., Meera, A. K., \& Saleem, M. Y. (2015). Factors influencing the behavioral intentions of muslim employees to contribute to cash-waqf through salary deductions. JKAU: Islamic Economics2, 28(1), 63-98.

Pollock, K., \& Hauseman, D. C. (2019). The Use of E-mail and Principals' Work: A DoubleEdged Sword. Leadership and Policy in Schools, 18(3), 382-393.

https://doi.org/10.1080/15700763.2017.1398338

Popoola, B. A., \& Chinomona, E. (2017). The influence of trust, communication and commitment on ethical behavior in universities: a case of South Africa. Problems and Perspectives in Management, 15, Iss. 2 (cont. 1), 266-276.

Rahi, S., \& Abd. Ghani, M. (2019). Does gamified elements influence on user's intention to adopt and intention to recommend internet banking? The International Journal of Information and Learning Technology, 36(1), 2-20. https://doi.org/10.1108/IJILT05-2018-0045

Rahman, A. H. A., Said, S., Salamun, H., Aziz, H., Adam, F., \& Ahmad, W. I. W. (2018). Sustainable development from islamic perspective. International Journal of Civil Engineering and Technology, 9(4), 985-992.

http://www.iaeme.com/ijciet/issues.asp?JType=IJCIET\&VType=9\&IType=4

Rasoolimanesh, S. M., Iranmanesh, M., Amin, M., Hussain, K., Jaafar, M., \& Ataeishad, H. (2020). Are functional, emotional and social values interrelated? A study of traditional guesthouses in Iran. International Journal of Contemporary Hospitality Management, 32(9), 2857-2880. https://doi.org/10.1108/IJCHM-03-2020-0193 
Ratnasari, R T, Gunawan, S., Talib, J. B. A., Herianingrum, S., Widiastuti, T., Septiarini, D. F., \& Fitrisia, D. (2020). The moderating effects of gender between patient intimacy, trust, and loyalty. International Journal of Innovation, Creativity and Change, 12(10), $1-16$.

Ratnasari, Ririn Tri, Gunawan, S., Fauzy, R. M. Q., \& Septiarini, D. F. (2018). Patient intimacy and innovation development to improve health service performance. International Journal of Engineering \& Technology, 7(2.29), 338-339.

Raza, S. A., Jawaid, S. T., \& Hassan, A. (2015). Internet banking and customer satisfaction in Pakistan. Qualitative Research in Financial Markets, 7(1), 24-36. https://doi.org/10.1108/QRFM-09-2013-0027

Rowley, J. (2016). Information marketing. Routledge.

Saifuddin, F. B., Kadibi, S., Polat, R., Fidan, Y., \& Kayadibi, O. (2014). The role of cash waqf in poverty alleviation: case of Malaysia.

Salleh, R., Nair, M. S., \& Harun, H. (2012). Job satisfaction, organizational commitment, and turnover intention: A case study on employees of a retail company in Malaysia. International Journal of Economics and Management Engineering, 6(12), 34293436.

Sanusi, S., \& Shafiai, M. H. M. (2015). The management of cash waqf: toward socioeconomic development of Muslims in Malaysia. Jurnal Pengurusan (UKM Journal of Management), 43.

Saputra, A., Alwie, A. F., \& Widayatsari, A. (2020). Pengaruh Promosi dan Kualitas Pelayanan terhadap Kepercayaan dan Loyalitas Donatur Dompet Dhuafa Riau (The Effect of Promotion and Quality of Service on the Trust and Loyalty of Dompet Dhuafa Riau). Jurnal Dakwah Risalah; Vol 31, No 1 (2020): Juni 2020. https://doi.org/10.24014/jdr.v31i1.10040

Sargeant, A., \& Jay, E. (2005). Redefining commitment. In Final Report.

Sawicki, V., \& Agnew, C. R. (2021). Commitment strength versus commitment bolstering: Uncertainty undermines and promotes relationship success. The Journal of Social Psychology, 161(1), 47-62. https://doi.org/10.1080/00224545.2020.1756194

Shaikh, S. A., Ismail, A. G., \& Mohd Shafiai, M. H. (2017). Application of for social and development finance. ISRA International Journal of Islamic Finance, 9(1), 5-14. https://doi.org/10.1108/IJIF-07-2017-002

Shang, J., Sargeant, A., \& Carpenter, K. (2019). Giving intention versus giving behavior: How differently do satisfaction, trust, and commitment relate to them? Nonprofit and Voluntary Sector Quarterly, 48(5), 1023-1044.

Sismujito, A. Z. S. (2016). Social Motivation And Peoples Participation In Development Of Rural Development In District Of West Of Nias Province North Sumatra. International Journal of Scientific \& Technology Research, 5(10).

Suhaimi, F. M., Rahman, A. A., \& Marican, S. (2014). The role of share waqf in the socioeconomic development of the Muslim community: The Malaysian experience. Humanomics, 30(3), 227-254.

Sulaiman, M., \& Zakari, M. A. (2015). Efficiency and effectiveness of waqf institutions in 
Malaysia: toward financial sustainability. Access to Finance and Human Development-Essays on Zakah, Awqaf and Microfinance, 43, 1330-2357.

Sutomo, S., Najib, M., \& Djohar, S. (2017). Pengaruh Kualitas Pelayanan Lembaga Amil Zakat (LAZ) Terhadap Kepuasan dan Loyalitas Muzakki (Studi Kasus LAZ PKPU Yogyakarta). Jurnal Aplikasi Bisnis Dan Manajemen (JABM), 3(1), 59.

Tambunan, M. R., \& Nasution, I. G. S. (2013). Analisis faktor-faktor yang mempengaruhi keputusan nasabah menabung di Bank BCA kota Medan (Studi kasus etnis Cina). Jurnal Ekonomi Dan Keuangan, 1(3), 14727.

Tjiptono, F. (2015). Pemasaran Jasa. Penerbit Andi.

Urbonavicius, S., Degutis, M., Zimaitis, I., Kaduskeviciute, V., \& Skare, V. (2021). From social networking to willingness to disclose personal data when shopping online: Modelling in the context of social exchange theory. Journal of Business Research, 136, 76-85.

Wang, K., \& Lin, C.-L. (2012). The adoption of mobile value-added services: Investigating the influence of IS quality and perceived playfulness. Managing Service Quality: An International Journal, 22(2), 184-208.

https://doi.org/10.1108/09604521211219007

Wang, Y., Xiang, D., Yang, Z., \& Ma, S. (Sara). (2019). Unraveling customer sustainable consumption behaviors in sharing economy: A socio-economic approach based on social exchange theory. Journal of Cleaner Production, 208, 869-879. https://doi.org/10.1016/j.jclepro.2018.10.139

Xie, X., \& Ding, Y. (2013). The Influence of Financial Information of Charity Foundations on Donations: An Empirical Test. Proceedings of the 2013 International Conference on the Modern Development of Humanities and Social Science. https://doi.org/10.2991/mdhss-13.2013.1

Yan, Z., Wang, T., Chen, Y., \& Zhang, H. (2016). Knowledge sharing in online health communities: A social exchange theory perspective. Information \& Management, 53(5), 643-653. https://doi.org/10.1016/j.im.2016.02.001

Yucel, I. (2012). Examining the Relationships among Job Satisfaction, Organizational Commitment, and Turnover Intention: An Empirical Study. International Journal of Business and Management, 7(20). https://doi.org/10.5539/ijbm.v7n20p44

Zainon, S., Atan, R., Wah, Y. B., \& Nam, R. Y. T. (2011). Institutional donors' expectation of information from the Non-Profit Organizations (NPOs) reporting: A pilot survey. International NGO Journal, 6(8), 70-180. https://doi.org/10.5897/NGOJ11.013

Zhao, L., Lu, Y., Zhang, L., \& Chau, P. Y. K. (2012). Assessing the effects of service quality and justice on customer satisfaction and the continuance intention of mobile valueadded services: An empirical test of a multidimensional model. Decision Support Systems, 52(3), 645-656. https://doi.org/10.1016/j.dss.2011.10.022

Zhao, Y., Ni, Q., \& Zhou, R. (2018). What factors influence the mobile health service adoption? A meta-analysis and the moderating role of age. International Journal of Information Management, 43, 342-350. https://doi.org/10.1016/j.ijinfomgt.2017.08.006 